\title{
PEMBENTUKAN FUNGSI PENGARUH METEOROLOGI PADA PERSAMAAN GAUSS MENGGUNAKAAN SOFTWARE R
}

\author{
Rachmanu Eko Handriyono ${ }^{1}$ \\ ${ }^{1}$ Teknik Lingkungan-ITATS, Jl. Arief Rahman Hakim 100 Surabaya \\ email: handriyono.rachmanu@itats.ac.id
}

\begin{abstract}
Air quality model is numerical tools to describe the air quality in an urban. One of the air quality models is gaussian model. Factors that influence the gaussian equation are the sources of pollution, meteorological factors, the kinetics of reactions in the atmosphere, and land forms. These studies formed the function of the influence of meteorology on gaussian equation of traffic activities in Ahmad Yani Street, Surabaya. Meteorological factors such as wind speed and direction, the distance from the source to the receptor, and the atmosphere stability is simulated using software applications $R$. The purpose of this study is to establish the code foundation of software $R$ for meteorological factors. The results showed the influence of meteorological function model using $R$ is able to produce the work easier and faster time. The influence of meteorological function form a formulation of dispersion coefficient $\sigma y$ dan $\sigma z$ requires variables such as pollution sources and receptor coordinates, wind direction and atmospheric stability class.
\end{abstract}

Keywords: air quality model, gaussian equation, software $R$

\begin{abstract}
ABSTRAK
Model kualitas udara merupakan perangkat numerik untuk menggambarkan kualitas udara di suatu wilayah perkotaan. Salah satu model kualitas udara yang bisa digunakan untuk memperkirakan kualitas udara diperkotaan yaitu model gauss. Faktor-faktor yang mempengaruhi persamaan Gauss yaitu sumber pencemar, faktor meteorologi, kinetika reaksi di atmosfer, dan bentuk lahan. Studi ini membentuk fungsi pengaruh meteorologi pada persamaan gauss dari kegiatan transportasi di Jalan Ahmad Yani, Surabaya. Faktor meteorologi berupa kecepatan dan arah angin, jarak dari sumber ke penerima, dan stabilitas atmosfer disimulasikan menggunakan aplikasi software $R$. Tujuan penelitian ini membentuk pondasi kode pada software $R$ untuk faktor meteorologi. Hasil penelitian menunjukkan model fungsi pengaruh meteorologi menggunakan software $R$ mampu menghasilkan pengerjaan yang lebih mudah dan waktu yang cepat. Fungsi pengaruh meteorologi berupa formulasi koefisien dispersi $\sigma \mathrm{y}$ dan $\sigma \mathrm{z}$ membutuhkan variabel berupa koordinat sumber pencemar dan receptor, arah angin, dan kelas stabilitas atmosfer.
\end{abstract}

Kata kunci: model kualitas udara, persamaan gauss, faktor meteorologi, software $R$

\section{PENDAHULUAN}

Pencemaran udara merupakan salah satu faktor besar terhadap penurunan kualitas udara di perkotaan. Pencemaran udara telah menjadi masalah serius karena dampaknya yang sangat merugikan bagi lingkungan dan kesehatan manusia [1]. Dalam beberapa tahun terakhir pencemaran udara menjadi masalah serius karena peningkatan gas polutan yang sangat pesat setiap harinya [2]. Saat ini, pencemaran udara dari berbagai sumber pencemar menjadi permasalahan utama di perkotaan [3]. Sumber pencemar udara di perkotaan didominasi oleh kegiatan transportasi dan kegiatan industri [4]. Kegiatan transportasi mempunyai kontribusi yang besar terhadap penurunan kualitas udara di perkotaan [5].

Untuk membuat gambaran kualitas udara perkotaan diperlukan suatu pemodelan. Ada beberapa model dispersi udara yang bisa digunakan untuk memperkirakan kualitas udara perkotaan, salah satunya yaitu model gauss. Beberapa faktor yang perlu mendapat perhatian dalam pembangunan model yaitu kecepatan dan arah angin, jarak dari sumber ke penerima, dan stabilitas atmosfer [6]. Penelitian ini menggunakan persamaan gauss untuk membentuk fungsi koefisien dispersi $\sigma \mathrm{y}$ dan $\sigma \mathrm{z}$ pada software $R$. Model gauss merupakan metode yang palling sesuai karena dapat memprediksi dispersi gas pencemar dari berbagai sumber yang terjadi di atmosfer [7]. Model gauss dapat memprediksi konsentrasi gas polutan untuk jangka panjang dengan arah dan kecepatan 
angin yang berubah dan sumber yang tak terbatas. Model dispersi gauss mempunyai kelebihan dapat diterapkan pada segala kondisi atmosfer [8].

Program simulasi prediksi penyebaran pencemar udara seperti AERMOD, CALINE4, ISCST3 membutuhkan banyak data serta biaya yang mahal. Penelitian ini ingin membuat program simulasi model kualitas udara yang tidak membutuhkan biaya mahal. Simulasi faktor meteorologi arah dan kecepatan angin, jarak dari sumber pencemar ke penerima, dan stabilitas atmosfer pada persamaan gauss menggunakan software $R$. Software $R$ adalah perangkat lunak lingkungan untuk analisis data dan grafis berbasis open source. Hasil simulasi tersebut akan membentuk fungsi koefisien dispersi $\sigma y$ dan $\sigma z$. Penelitian ini menggunakan studi kasus kegiatan transportasi di Jalan Ahmad Yani Surabaya sebagai sumber pencemar. Kegiatan transportasi merupakan penyumbang terbesar gas polutan udara di negara-negara berkembang [9]. Tujuan penelitian ini membentuk pondasi kode pada software $R$ untuk setiap faktor dari persamaan gauss. Harapannya agar terbentuk pondasi kode setiap faktor dari persamaan gauss pada software $R$ sehingga bisa digunakan oleh banyak orang secara gratis.

\section{KAJIAN PUSTAKA}

Penyebaran polutan di udara sangat dipengaruhi oleh faktor meteorologi kecepatan dan arah angin. Faktor meteorologi mempengaruhi perpindahan polutan dari sumber ke penerima [10]. Kecepatan dan arah angin menunjukkan daerah yang paling tercemar oleh polutan. Perubahan arah dan kecepatan angin menunjukkan arah penyebaran dan fluktuasi konsentrasi zat pencemar di atmosfer. Perubahan angin juga dipakai untuk menentukan kelas stabilitas atmosfer. Tabel 1 menunjukkan kategori stabilitas atmosfer.

Tabel 1. Kategori stabilitas atmosfer [11]

\begin{tabular}{|c|c|c|c|c|c|}
\hline \multirow{3}{*}{$\begin{array}{c}\text { Kecepatan angin } \\
\text { permukaan pada } \\
\text { ketinggan } 10 \mathrm{~m} \\
(\mathrm{~m} / \mathrm{dt})\end{array}$} & \multicolumn{3}{|c|}{ Siang } & \multicolumn{2}{|c|}{ Malam $^{*}$} \\
\hline & \multicolumn{3}{|c|}{ Radiasi Sinar Matahari } & \multicolumn{2}{|c|}{ Kondisi Awan } \\
\hline & Kuat & Sedang & Lemah & Mendung & Cerah \\
\hline$<2$ & A & A-B & B & $\mathrm{E}$ & $\mathrm{F}$ \\
\hline $2-3$ & A-B & B & $\mathrm{C}$ & $\mathrm{E}$ & $\mathrm{F}$ \\
\hline $3-5$ & B & B-C & $\mathrm{C}$ & D & $\mathrm{E}$ \\
\hline $5-6$ & $\mathrm{C}$ & C-D & $\mathrm{D}$ & $\mathrm{D}$ & $\mathrm{D}$ \\
\hline$>6$ & $\mathrm{C}$ & $\mathrm{D}$ & $\mathrm{D}$ & $\mathrm{D}$ & $\mathrm{D}$ \\
\hline
\end{tabular}

*Malam didefinisikan sebagai periode dari 1 jam sebelum matahari tenggelam dan 1 jam setelah matahari terbit.

Keterangan:

$\mathrm{A}=$ sangat labil $\mathrm{C}=$ sedikit labil $\quad \mathrm{E}=$ agak stabil

$$
\mathrm{B}=\text { labil } \quad \mathrm{D}=\text { netral } \quad \mathrm{F}=\text { stabil }
$$

Sebagian besar pemodelan kualitas udara menggunakan pendekatan matematis menggunakan persamaan gauss. Model Gauss mendeskripsikan pencampuran pencemar udara di atmosfer dari sumber pencemar yang disebabkan oleh turbulensi pada arah vertikal dan horizontal [12]. Model gauss menggunakan pendekatan antara lain yaitu fungsi beban emisi dari sumber pencemar, fungsi pengaruh meteorologi, dan fungsi konsentrasi gas polutan yang terbentuk. Gambar 1 menunjukkan tipikal pola dispersi udara dari sumber garis/transportasi (line source). 


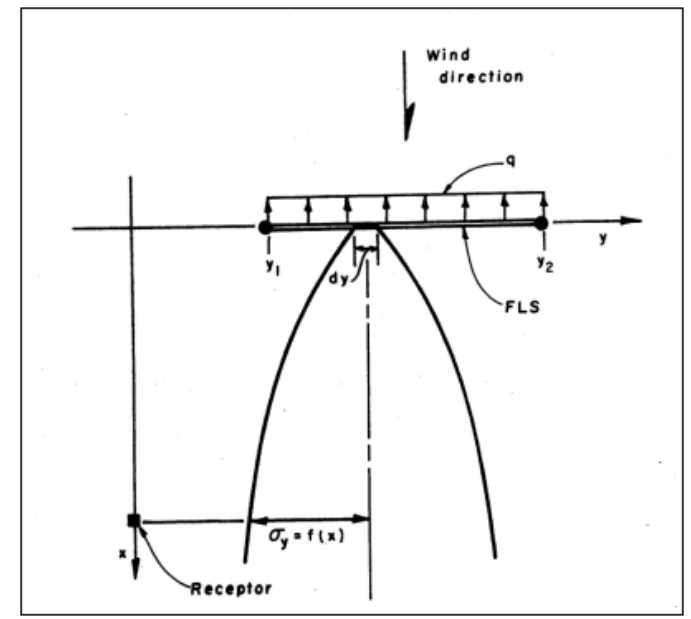

Gambar 1. Tipikal pola dispersi udara dari sumber garis (line source) [13]

Penelitian ini membentuk fungsi pengaruh meteorologi dari kegiatan transportasi menggunakan software $R$ berbasis open source. Open source adalah suatu konsep yang menunjuk pada produksi dan pengembangan praktis dimana setiap orang dapat mengakses pada sumber (source) suatu produk akhir. Harapannya terbentuk pondasi kode dari setiap fungsi persamaan gauss pada software $R$ sehingga setiap orang bisa mengakses dan menggunakan secara terbuka.

\section{METODE}

Pembentukan fungsi pengaruh meteorologi persamaan gauss menggunakan data primer berupa koordinat sumber pencemar dan titik penerima serta data sekunder berupa arah angin. Sumber pencemar berasal dari kegiatan transportasi di Jalan Ahmad Yani Surabaya dan titik penerima adalah stasiun pemantau kualitas udara SUF 7 di daerah kebonsari (Gambar 2), sedangkan data sekunder berupa arah angin berasal dari BLH Kota Surabaya. Arah angin menggunakan data 1 bulan yaitu bulan Februari 2016. Perhitungan fungsi pengaruh meteorologi pertama menggunakan microsoft excell kemudian ditransformasikan ke dalam software $R$. Simulasi pembentukan fungsi pengaruh meteorologi menggunakan Tinn- $R$ versi 3.0.3.6 dan untuk running fungsi menggunakan $R$ versi 3.1.2.

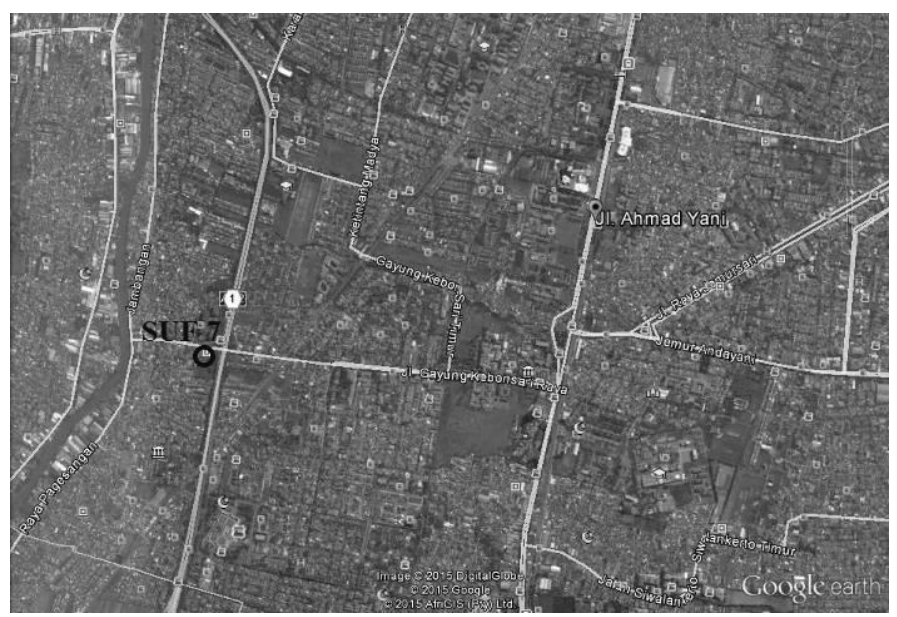

Gambar 2. Lokasi penelitian

Fungsi persamaan dasar gauss adalah sebagai berikut [13]:

$$
C=\frac{\mathrm{Q}}{2 \pi \cdot u \cdot \sigma y \cdot \sigma z} \exp \left(-\frac{1}{2} \cdot \frac{y^{2}}{\sigma y^{2}}\right)\left\{\exp \cdot\left(-\frac{1}{2} \frac{(Z-H)}{\sigma z^{2}}\right)+\exp \left(-\frac{1}{2} \frac{(Z+H)}{\sigma z^{2}}\right)\right\}
$$


Dengan $\mathrm{C}=$ konsentrasi polutan $\left(\mu \mathrm{g} / \mathrm{m}^{3}\right), \mathrm{Q}=$ beban emisi $(\mathrm{g} / \mathrm{km}$.jam $), \mathrm{y}=$ jarak horizontal dari titik tengah plume, $\mathrm{Z}=$ jarak vertikal dari permukaan tanah $(\mathrm{m}), \mathrm{H}=$ ketinggian stack $(\mathrm{m}), \mathrm{u}=$ kecepatan angin (m/detik), $\sigma \mathrm{y}=$ koefisien dispersi horizontal $(\mathrm{m}), \sigma \mathrm{Z}=$ koefisien dispersi vertikal (m). Koefisien dispersi $\sigma y$ dan $\sigma z$ merupakan fungsi dari pengaruh meteorologi. Adapun persamaan koefisien dispersi $\sigma y$ dan $\sigma z$ adalah sebagai berikut:

$\sigma y=a x^{b}$

$\sigma z=c x^{b}+f$

Dengan $\mathrm{x}=$ jarak sumber pencemar ke receprtor $(\mathrm{m}), \mathrm{a}, \mathrm{b}, \mathrm{c}, \mathrm{f}=\mathrm{konstan}$ stabilitas atmosfer (Tabel 2).

Tabel 2. Konstan stabilitas atmosfer [13]

\begin{tabular}{ccccccccc}
\hline \multirow{2}{*}{ Stabilitas } & \multirow{2}{*}{$\mathrm{a}$} & $\mathrm{b}$ & \multicolumn{3}{c}{$\mathrm{x}<1 \mathrm{~km}$} & $\mathrm{c}$ & $\mathrm{x} \times 1 \mathrm{~km}$ \\
\cline { 4 - 8 } & & & $\mathrm{c}$ & $\mathrm{d}$ & $\mathrm{f}$ & $\mathrm{C}$ & $\mathrm{d}$ & $\mathrm{f}$ \\
\hline $\mathrm{A}$ & 213 & 0,894 & 440,8 & 1,941 & 9,27 & 459,7 & 2,094 & $-9,6$ \\
$\mathrm{~B}$ & 156 & 0,894 & 106,6 & 1,149 & 3,3 & 108,2 & 1,098 & 2 \\
$\mathrm{C}$ & 104 & 0,894 & 61 & 0,911 & 0 & 61 & 0,911 & 0 \\
$\mathrm{D}$ & 68 & 0,894 & 33,2 & 0,725 & $-1,7$ & 44,5 & 0,516 & -13 \\
E & 50,5 & 0,894 & 22,8 & 0,678 & $-1,3$ & 55,4 & 0,305 & -34 \\
F & 34 & 0,894 & 14,35 & 0,74 & $-0,35$ & 62,6 & 0,18 & $-48,6$ \\
\hline
\end{tabular}

Jarak x dan y merupakan hubungan arah angin dan jalan dengan sumber penerima (Gambar 3), sehingga

$X=(S p-S r) \operatorname{Cos} \theta+(R p-R r) \operatorname{Sin} \theta$

$Y=(S p-S r) \operatorname{Sin} \theta+(R p-R r) \operatorname{Cos} \theta$

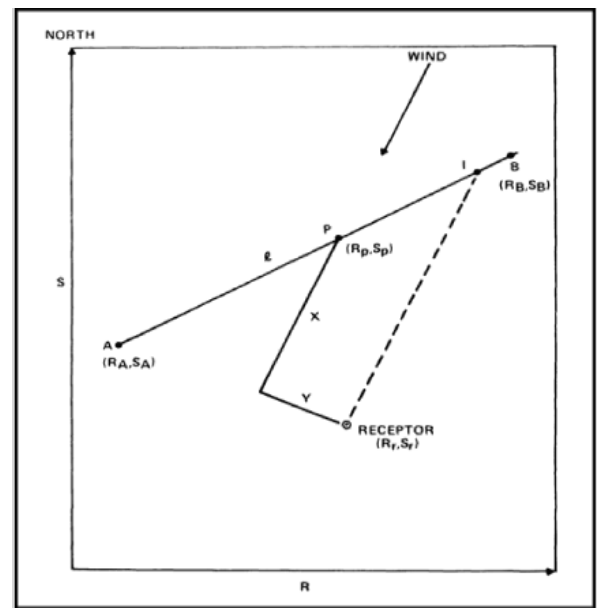

Gambar 3. Hubungan arah angin, jalan, dan titik penerima [14]

\section{HASIL DAN PEMBAHASAN}

Arah angin digunakan untuk mengetahui jarak dispersi gas polutan dari sumber pencemar ke titik penerima dan menentukan titik koordinat sumber pencemar. Tabel 3 adalah arah angin ratarata pada bulan Februari 2016. Arah angin bulan Februari 2016 menunjukkan rata-rata ke arah Barat. 
Tabel 3. Arah angin rata-rata Februari 2016

\begin{tabular}{ccc}
\hline Hari & Arah angin $\left(^{\circ}\right)$ & Kecepatan angin $(\mathrm{m} / \mathrm{s})$ \\
\hline Senin & 262 & 1,74 \\
Selasa & 281 & 1,40 \\
Rabu & 291 & 1,31 \\
Kamis & 286 & 1,46 \\
Jumat & 282 & 1,73 \\
Sabtu & 275 & 1,75 \\
Minggu & 250 & 1,64 \\
\hline
\end{tabular}

Adapun koordinat Jalan Ahmad Yani adalah $7^{\circ} 20^{\prime} 3.21^{\prime \prime} \mathrm{S}-112^{\circ} 43^{\prime} 48.02^{\prime \prime}$ E dan koordinat SUF 7 adalah $7^{\circ} 19^{\prime} 42.30^{\prime \prime} \mathrm{S}-112^{\circ} 42^{\prime} 49.90 "$ E. Kemudian melakukan perhitungan jarak x dan y yang merupakan hubungan antara angin, sumber pencemar, dan titik penerima menggunakan persamaan (4) dan (5). Tabel 4 adalah hasil perhitungan jarak x dan $\mathrm{y}$.

Tabel 4. Hasil perhitungan jarak $\mathrm{x}$ dan $\mathrm{y}$

\begin{tabular}{ccccc}
\hline Hari & Arah angin & Kecepatan angin $(\mathrm{m} / \mathrm{s})$ & $\mathrm{x}(\mathrm{m})$ & $\mathrm{y}(\mathrm{m})$ \\
\hline Senin & 262,25 & 1,74 & 1836 & 513 \\
Selasa & 281,39 & 1,40 & 1612 & 1017 \\
Rabu & 291,06 & 1,31 & 1317 & 1378 \\
Kamis & 286,24 & 1,46 & 1229 & 1458 \\
Jumat & 281,57 & 1,73 & 1404 & 1290 \\
Sabtu & 275,40 & 1,75 & 1250 & 1440 \\
Minggu & 249,76 & 1,64 & 1792 & 651 \\
\hline
\end{tabular}

Setelah mengetahui jarak $\mathrm{x}$ dan $\mathrm{y}$, lalu menghitung koefisien dispersi $\sigma \mathrm{y}$ dan $\sigma \mathrm{z}$ menggunakan persamaan (2) dan (3). Tabel 5 adalah hasil perhitungan koefisien dispersi $\sigma y$ dan oz. Hasil perhitungan menunjukkan dispersi gas polutan terjauh terjadi pada hari senin dengan jarak horizontal oy sejauh $28146 \mathrm{~m}$ dan jarak vertikal $\sigma y$ sejauh $194 \mathrm{~m}$.

Tabel 5. Hasil perhitungan koefisien dispersi $\sigma \mathrm{y}$ dan $\sigma \mathrm{z}$

\begin{tabular}{ccccccc}
\hline Hari & $\begin{array}{c}\text { Arah angin } \\
\left({ }^{\circ}\right)\end{array}$ & $\begin{array}{c}\text { Kecepatan } \\
\text { angin }(\mathrm{m} / \mathrm{s})\end{array}$ & $\mathrm{x}(\mathrm{m})$ & $\mathrm{y}(\mathrm{m})$ & $\sigma \mathrm{y}(\mathrm{m})$ & $\sigma \mathrm{z}(\mathrm{m})$ \\
\hline Senin & 262,25 & 1,74 & 1836 & 513 & 41807 & 514 \\
Selasa & 281,39 & 1,40 & 1612 & 1017 & 37221 & 493 \\
Rabu & 291,06 & 1,31 & 1317 & 1378 & 31066 & 461 \\
Kamis & 286,64 & 1,46 & 1699 & 864 & 39012 & 501 \\
Jumat & 281,57 & 1,73 & 1404 & 1290 & 32894 & 471 \\
Sabtu & 275,40 & 1,75 & 1250 & 1440 & 29637 & 454 \\
Minggu & 249,76 & 1,64 & 1792 & 651 & 40900 & 510 \\
\hline
\end{tabular}

Setelah melakukan perhitungan menggunakan microsoft excell, kemudian mentransformasikan ke dalam software $R$. Semua kode persamaan matematis dicatat menggunakan Tinn-R versi 3.0.3.6. Secara garis besar, pembentukan fungsi suatu model persamaan adalah meringkas semua formula matematis ke dalam bentuk fungsi sederhana dengan memasukkan variabel yang dibutuhkan. Gambar 4 dan Gambar 5 merupakan hasil pembentukan fungsi pengaruh meteorologi koefisien dispersi $\sigma \mathrm{y}$ dan $\sigma \mathrm{z}$ dari sumber transportasi. 


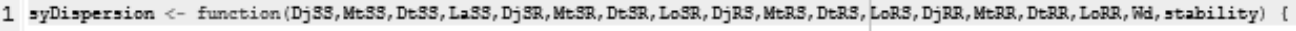
nilais <- vector ()

if $($ L 2 SS $=$ "Bouth") $3 g<-(\mathrm{DjSB}+\mathrm{MtSB} / 60+\mathrm{DtSB} / 3600)$

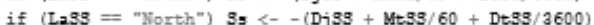

if $($ LaSR $=$ "South") $3 \mathbf{x}<-(\mathrm{Dj}$ SR + MtSR $/ 60+\mathrm{DtSR} / 3600)$

if $\left(\mathrm{L}_{2} \mathrm{SR}=\right.$ "North") $\mathrm{S}_{\mathbf{r}}<-(\mathrm{Dj} \mathrm{DR}+\mathrm{MtSR} / 60+\mathrm{DtSR} / 3600)$

nilais[1] $<-3$ s

nilais $[2]<-3 x$

$S<-a b s(($ nilais [1]-nilais [2] $)+60)$

nilaiR <- vector()

if $($ LoR3 $=$ "East") $R \mathbf{s}<-($ DjRS + MtR3/60 + DtR3/3600)

if (LoRS = "West") $R=<-$ (DjRS + MtRB/60 + DtRB/3600)

if $($ LoRR $=$ " "Zast") $\mathrm{Rr}<-(\mathrm{Dj} R \mathrm{RR}+\mathrm{MtRR} / 60+\mathrm{DtRR} / 3600)$

if (LoRR = "West") $\mathrm{Rx}<--(\mathrm{DjRR}+\mathrm{MtRR} / 60+\mathrm{DtRR} / 3600)$

nilaiR [1] $<-R=$

nilaiR $[2]<-R x$

$\mathrm{R}<-\operatorname{abs}(($ nilaiR $[1]-$ nilaiR $[2])+60)$

$\mathrm{X}<-\operatorname{abs}\left(\left(\mathrm{S}^{+}+\cos (\mathrm{Wd})\right)+\left(\mathrm{R}^{+} \sin (\mathrm{Wd})\right)+1852\right.$

kongtan $1<-$ vector $(0)$

if $(\mathrm{X}<1000)$ (

if (stability $=" \mathrm{~A} ")$ ) ronstan1 <- $c(213,0.894,440.8,1.941,9.27)$

if (stability $=$ "B") kongtan1 <- $c(156,0.894,106.6,1.149,3.3)$

if (stability $=" C ")$ kongtan1 $<-c(104,0.894,61,0.911,0)$

if (stability $=$ "D") kongtan1 $<-c(68,0.894,33.2,0.725,-1.7)$

if (stability $=" \mathrm{E} ")$ konstan1 $<-c(50.5,0.894,22.8,0.678,-1.3)$

if (stability $\left.=" F^{\prime \prime}\right)$ kongtan1 $<-c(34,0.894,14.35,0.74,-0.35)$

] else [

if $(\mathrm{X}>1000)$

if (stability $=" \mathrm{~A} "$ ) konstan1 <- $c(213,0.894,459.7,2.094,-9.6)$

if (stability $=" B ")$ konstan1 <- $c(156,0.894,108.2,1.098,2)$

if (stability $=" C "$ ") ) rongtan1 $<-c(104,0.894,61,0.911,0)$

if (stability $=$ "D") kanstan1 <- C (68,0.894,33.2, 44.5, $0.516,-13)$

if (stability $=" \mathrm{E} ")$ kongtan1 $<-c(50.5,0.894,55.4,0.305,-34)$

了

if (stability $="$ "F" $^{\prime \prime}$ ) konstan1 $<-c(34,0.894,62.6,0.18,-48.6)$

kongtan <- kongtan $1[1]$

bkongtan <- konstan1 [2]

cronstan <- konstan1 [3]

dronstan <- konstan1 [4]

frongtan <- konstan 1 [5]

sy <- (ronstan $1[1]^{+}\left(\mathrm{X}^{\wedge}\right.$ konstan 1 [2] $)$

return (sy)

Gambar 4. Fungsi koefisien dispersi $\sigma y$

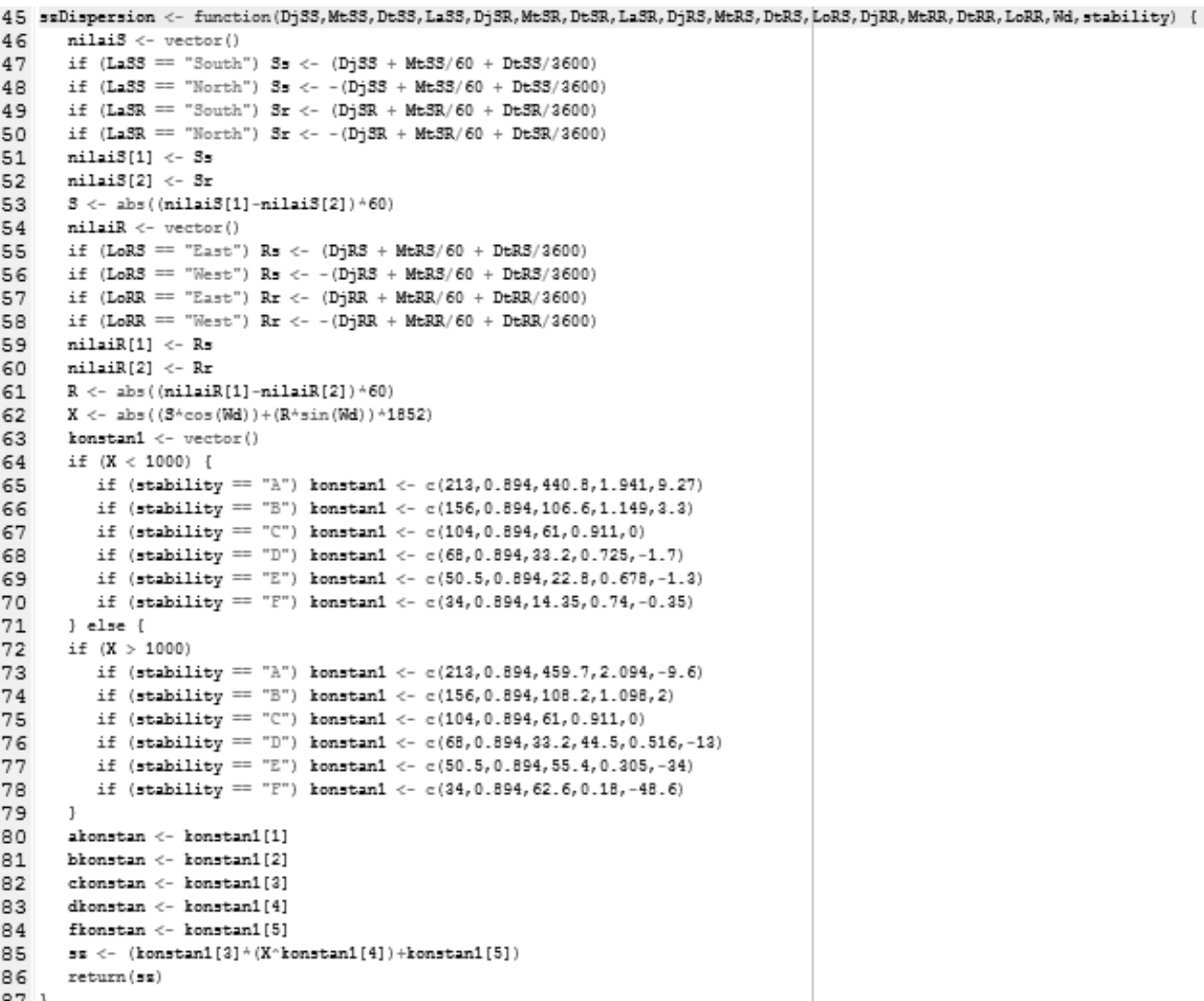

Gambar 5. Fungsi koefisien dispersi $\sigma \mathrm{z}$ 
Pada fungsi diatas, variabel $\mathrm{DjSS}=$ derajat koordinat $\mathrm{S}$ di sumber pencemar (source), $\mathrm{MtSS}=$ menit koordinat $\mathrm{S}$ di source, $\mathrm{DtSS}=$ detik koordinat $\mathrm{S}$ di source, $\mathrm{LaSS}=$ arah lintang (latitude) di source, $\mathrm{DjSR}=$ derajat koordinat $\mathrm{S}$ di penerima (receptor), $\mathrm{MtSR}=$ menit koordinat $\mathrm{S}$ di receptor, $\mathrm{DtSR}=$ detik koordinat $\mathrm{S}$ di receptor, $\mathrm{LaSR}=$ arah lintang (latitude) di receptor, $\mathrm{DjRS}=$ derajat koordinat $\mathrm{R}$ di source, $\mathrm{MtRS}=$ menit koordinat $\mathrm{R}$ di source, $\mathrm{DtRS}=$ detik koordinat $\mathrm{R}$ di source, $\mathrm{LoRS}=$ arah bujur (longitude) di source, $\mathrm{DjRR}=$ derajat koordinat $\mathrm{R}$ di receptor, $\mathrm{MtRR}=$ menit koordinat $\mathrm{R}$ di receptor, $\mathrm{DtRR}=$ detik koordinat $\mathrm{R}$ di receptor, $\mathrm{LoRR}=$ arah bujur (longitude) di receptor, $\mathrm{Wd}=$ arah angin, dan Stability $=$ kelas stabilitas atmosfir.

Setelah mendapatkan fungsi tersebut kemudian melakukan running menggunakan aplikasi $R$. Caranya adalah mengcopy fungsi yang terbentuk dari aplikasi Tinn $R$ ke aplikasi $R$. Kemudian memasukkan nilai variabel yang akan digunakan. Penelitian ini menggunakan kategori stabilitas kelas "E" yaitu agak stabil. Gambar 3 dan Gambar 4 merupakan hasil running fungsi koefisien dispersi $\sigma y$ dan $\sigma z$ pada hari senin. Sedangkan Gambar 5 adalah rekapitulasi hasil running koefisien dispersi $\sigma \mathrm{y}$ dan $\sigma \mathrm{z}$.

syDispersion (7,20,3,21,"South",7,19,42,3,"South",112,43,48.02, "East",112,42,49.9, "East",262.25,"E") [1] 40848.18

Gambar 3. Hasil running fungsi koefisien dispersi oy pada hari Senin

> szDispersion (7,20,3.21,"South", 7, 19,42.3,"South",112,43,48.02, "East", 112,42, 49.9, "East", 262.25, "E") [1] 509.9666

Gambar 4. Hasil running fungsi koefisien dispersi oz pada hari Senin

\begin{tabular}{|c|c|c|c|c|c|c|c|c|c|c|c|c|c|c|c|c|c|c|c|c|c|}
\hline & Hari & DjSS & MtSS & DtSS & Lass & DjSR & MtSR & DtSR & LaSR & DjRS & ItRS & DtRS & LoRS & $\mathrm{Dj} \mathrm{RB}$ & tRR & $\mathrm{DtRI}$ & $\mathrm{L} \circ \mathrm{RR}$ & Wd & Stability & sy & $3 z$ \\
\hline 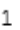 & Senin & 7 & 20 & 3.21 & South & 7 & 19 & 42.3 & South & 112 & 43 & 48.02 & East & 112 & 42 & 49.9 & East & 262.25 & E & 40848 & 509.97 \\
\hline 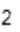 & Selasa & 7 & 20 & 3.21 & South & 7 & 19 & 42.3 & South & 112 & 43 & 48.02 & ast & 112 & 42 & 49. & ast & 281.39 & E & 30 & 506.46 \\
\hline B & Rabu & 7 & 20 & .21 & South & 7 & 19 & .3 & South & 112 & 43 & 48.02 & East & 112 & 42 & 49.9 & East & .06 & E & $E$ & .25 \\
\hline 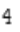 & Kamis & 7 & 20 & .21 & South & 7 & 19 & 42.3 & South & 112 & 43 & 48.02 & East & 112 & 42 & 49.9 & East & 286.24 & F & 13 & 451.18 \\
\hline 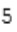 & Jumat & 7 & 20 & 3.21 & South & 7 & 19 & 42.3 & South & 112 & 43 & 48.02 & East & 112 & 42 & 49.9 & East & 281.57 & E & 38077 & 497.08 \\
\hline 5 & Sabtu & 7 & 20 & .21 & South & 7 & 19 & 2.3 & South & 112 & 43 & 48.02 & East & 112 & 42 & 49.9 & Cast & 275.40 & E & 36239 & 488.19 \\
\hline & Minggu & 7 & 20 & .21 & South & 7 & 19 & 2.3 & South & 112 & 43 & 48.02 & ast & 112 & 42 & 49.9 & ast & 249.76 & E & 40945 & 510.41 \\
\hline
\end{tabular}

Gambar 5. Rekapitulasi hasil running koefisien dispersi $\sigma \mathrm{y}$ dan $\sigma \mathrm{z}$

Hasil running pada aplikasi R sedikit berbeda dengan perhitungan di microsoft excell karena perbedaan angka dibelakang koma pada arah angin. Hasil perhitungan menunjukkan bahwa koefisien dispersi $\sigma y$ dan $\sigma z$ terbesar terjadi pada hari senin yaitu $41807 \mathrm{~m}$ ke arah horizontal dan 514 ke arah vertikal. Hasil perhitungan menunjukkan bahwa koefisien dispersi $\sigma y$ dan $\sigma z$ sangat dipengaruhi oleh arah angin dan jarak x (sumber pencemar ke receptor) yang dihasilkan. Semakin jauh jarak sumber pencemar ke receptor maka semakin jauh arah dispersi horizontal dan vertikal yang ditimbulkan. Hasil penelitian ini menunjukkan bahwa bentuk fungsi pengaruh meteorologi pada software $R$ mampu menghasilkan koefisien dispersi $\sigma y$ dan $\sigma \mathrm{z}$ dengan pengerjaan yang lebih mudah dan waktu pengerjaan yang lebih efisien. Bentuk fungsi ini membutuhkan variabel berupa koordinat sumber pencemar dan receptor, arah angin, dan kelas stabilitas atmosfer. Fungsi ini merupakan dasar dari pembentukan fungsi model gauss untuk software $R$. Oleh karena itu, studi ini mengharapkan adanya penelitian selanjutnya untuk membentuk fungsi model gauss pada software $R$ sehingga bisa melakukan validasi dengan model gauss pada penelitian yang lain.

\section{KESIMPULAN}

Penelitian ini menghasilkan kesimpulan sebagai berikut:

1. Fungsi pengaruh meteorologi pada software $R$ mampu menghasilkan formulasi koefisien dispersi $\sigma y$ dan $\sigma z$ dengan pengerjaan yang lebih mudah dan waktu pengerjaan yang lebih efisien.

2. Formulasi koefisien dispersi $\sigma y$ dan $\sigma z$ membutuhkan variabel berupa koordinat sumber pencemar dan receptor, arah angin, dan kelas stabilitas atmosfer.

3. Semakin jauh jarak sumber pencemar ke receptor maka semakin jauh arah dispersi horizontal dan vertikal yang ditimbulkan. 


\section{DAFTAR PUSTAKA}

[1] Nana, B., Sanogo, O., Savadogo, P. W., Daho, T., Bouda, M., dan Koulidiati, J. 2012. Air Quality Study in Urban Centers: Case Study of Ouagadougou, Burkina Faso. FUTY Journal of the Enviromnent, 7, 1597-8826.

[2] Zhou, M., He, G., Liu, Y., Yin, P., Li, Y., Kan, H., Fan, M., Xue, A., dan Fan, M. 2015. The Association Between Ambient Air Pollution and Adult Respiratory Mortality in 32 Major Chinese Cities, 2006-2010. Environmental Research, 137, 278-286.

[3] Wakamatsu, S., Morikawa, T., Ito, A. 2013. Air Pollution Trends in Japan between 1970 and 2012 and Impact or Urban Air Pollution Countermeasures. Asian Journal of Atmospheric Environment, 7, 177-190.

[4] Prakash, B. M., Shobhan, M., Mahadeva, S. M., dan Mahesh, S. 2017. Prediction of Air Pollutant Dispersion from Point and Line Sources and Validation of ISCST3 and Caline4 Model Data with Observed Values in the Industrial Area of Mysuru. International Journal of Innovative Research in Science, Engineering and Technology, 6, 18333-18350.

[5] Gonzalez, D., dan Cogliati, M. 2016. Study of vehicle emissions between Neuquen and Centenario, Argentina. Atmosfera, 29, 267-277.

[6] Prueksakorn, K., Kim, T., Kim, S., Kim, H., Kim, K. Y., Son, W., dan Vongmahadlek. 2012. Review of Air Dispersion Modelling Approaches to Assess The Risk of Wind-borne Spread of Foot-and-mouth Disease Virus. Journal of Environmental Protection, 3, 1260-1267.

[7] Nana, B., Sanogo, O., Savadogo, P. W., Daho, T., Bouda, M., dan Koulidiati, J. 2012. Air Quality Study in Urban Centers: Case Study of Ouagadougou, Burkina Faso. FUTY Journal of the Environment, 7, 1-18.

[8] Briant, R., Seigneur, C., Gadrat, M., dan Bugajny, C. 2013. Evaluation of Roadway Gaussian Plume Models with Large-scale Measurement Campaigns. Geoscientific Model Development, 6, 445-456.

[9] Kumar, P., Morawska, L., Martani, C., Biskos, G., Neophytou M., Sabatino, S. D., Bell, M., Norford, L., dan Britter, R. 2015. The Rise of Low-cost Sensing for Managing Air Pollution in Cities. Environment International, 75, 199-205.

[10] Vinayagam, A., Kavitha, C., Thangadurai, K. 2016. Multi Model Air Pollution Estimation for Environmental Planning Using Data Mining. International Journal of Science and Research, 3, 332-335.

[11] Cooper, C. D., dan Alley, F. C. 2002. Air Pollution Control $3^{\text {rd }}$ Edition. Waveland Press Inc. USA.

[12] Nagpure, A. S., dan Gurjar, B. R. 2014. Urban Traffic and Associated Environmental Impacts in India. Novel Combustion Concepts for Suistanable Energy Development, 405414. Springer India.

[13] Benson, P. 1989. Caline4 - A Dispersion for Predicting Air Pollutant Concentrations Near Roadways. Office of Transportation Laboratory. California.

[14] Petersen, W. B. 1978. A Gaussian-Plume Algorithm for Point, Area, and Line Sources. Environmental Science Researh Laboratory Office of Research and Development. North Carolina. 